УДК: $7.034(450) 6$

ББК: 85.103 (4)5

DOI: $10.18688 / \mathrm{aa} 2111-06-48$

F. Dubard de Gaillarbois

\title{
Varchi, Bronzo, Benvenuto... Ut pictura poësis sub specie mortis
}

Death will be considered in this essay not so much as an occasion to remember, mourn, pray, but to create, collaborate, and compare one's skills and performances. This point will be illustrated by various collaborations between a man of letters, Benedetto Varchi (1503-1565) and two of his many artist friends - Agnolo Bronzino (1503-1572) and Benvenuto Cellini (1500-1571) - whose artistic, poetic, and prosaic works appear strongly and durably linked to Varchi as Varchi's aesthetic sensitivity and artistic culture were, no doubt, indebted to his "artist" friends.

In his multifaceted relation with artists, Varchi played all kinds of roles: a corrector, a reviewer, a coach for literary challenges (as the famous 1547 anthology of letters in which both participated), an author of Latin mottoes and poetic reviews, an editor, but also a patron, an advisor, a broker, and an iconographist. Eventually, Varchi turned out to be not only a literary and intellectual mentor but also a spiritual guide... as death became for all of them not only a job opportunity or a topic to address, but a personal and imminent challenge.

Death offers a new angle to address the relations between the three of them and the extent and quality of a life-lasting critical dialogue, in which the "paragonian" dispute provided a useful and unavoidable mental kit. However, our point will be to show that in Varchi's circle, paragone worked more as a role game than a rigid grid, eventually giving way to pre-baroque aesthetics such as in Michelangelo's funerals (1564).

Starting with a matter-of-fact observation, Varchi, Bronzino, and Cellini's longevity exposed them to the loss of parents, friends, lovers, patrons, and masters alike. Some of these losses would lend themselves to a more or less elaborate mourning and burial strategies, depending on financial means, level of proximity with the deceased person, and status of the commission (private, academic, stately).

Between private death, such as Giovanni Cellini's (1563), and public funerals (Stefano Colonna (1548), Lucrezia de' Medici (1561), Michelangelo Buonarroti (1564)) stand the funerals of common friends or fellow artists (Tribolo (1550), Pontormo (1557), Luca Martini (1560)...) who didn't receive a state funeral, but whose links with the Academy and the court led to choral homage as miscellanies ${ }^{1}$ or a place in a burial $\operatorname{spot}^{2}$. As well known, the foundation of the

Mostly unpublished, some published when the deceased was prominent (Michelangelo, Varchi himself).

After being celebrated by his friends in an unpublished miscellany (19 sonnets of 6 different authors in "Nella Morte Di Maestro Jacopo da Puntormo Pittore", in Bronzino's papers) Pontormo was re-buried in 1562 in the burial spot, purchased and donated by Giovanni Agnolo Montorsoli. Bronzino and Allori would keep figuring Pontormo in frescoes in the middle of living persons to claim a living legacy. 
Accademia del Disegno (1564) resulted from the will of giving a proper funeral and tomb to the artists who could not afford it. Celebrating the death of their members was one of the core activities of any academy. Montorsoli and Pontormo had paved the way.

\section{From Stefano Colonna's funeral to Lucrezia de'Medici's funeral}

Stefano Colonna's funeral (1548) offers a seminal example of a standard cooperation between a man of letters - Varchi's funeral oration (Cf. [17]) - providing the speech, and a painter,- Bronzino - supplying the image in the form of a portrait (1546), made two years before the death of this cultivated condottiere. Being a member of the Florentine Academy might explain the choice of two fellow members regarding the funeral celebration.

Stefano could boast of an ancestor, Fabrizio Colonna, whom Machiavelli had entrusted with the part of the professional soldier discussing with civilians in the Art of war. He could also be considered an ex-republican, having fought for the Republic against Imperials and Medici to change sides after the siege. This political parable might explain why Varchi was chosen as an orator as he would later be in 1564 for another illustrious republican, Michelangelo, whom Cosimo had tried unsuccessfully to repatriate.

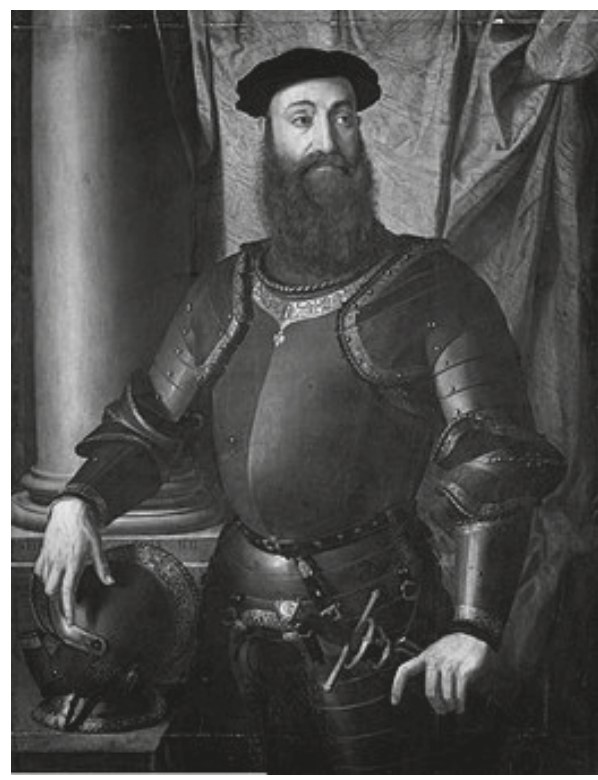

Fig. 1. Bronzino. Stefano Colonna. Galleria Barberini, 1546. Available at: https://www.wikidata.org/wiki/ Q28113318

The portrait of S. Colonna (Fig. 1) might have been commissioned by Cosimo to Bronzino as a token of gratitude for Colonna's efficiency and loyalty setting an example for ex-republicans. Moreover, Colonna must have been an art connoisseur and collector as he offered Cosimo a Greek statue in 1548, which later would be transformed by Cellini [2, II, 69] into a Ganymede (Fig. 2).

In 1548, Varchi did not mention Colonna's portrait in front of which he had delivered his funeral oration, but thirteen years later he would do it in Lucrezia's oration, in a rather duplicitous way: praising the portrait at first only to lessen it, after, using it (Fig. 3), ravishing as it was, as a faire-valoir of a moral portrait ${ }^{3}$ entrusted to literature:

E se pure alcuno è in questo luogo, il quale o non la vedesse giammai, o delle sue fattezze non gli sovvenga, e per conseguenza non creda vero cio, ch'io delle bellezze, e manière sue dico, miri (se gli piace) miri quella tavola, che mè posta al dirimpetto, nella quale vive la vera imagine di lei, da dotta, e maestrevole mano di saggio, ed

\footnotetext{
3 "E se egli ci diletta il vedere l'immagine corporale della amata persona; quanto più ci consolerà scorgere un vero ritratto dell'animo suo" [3, p. 13].
} 


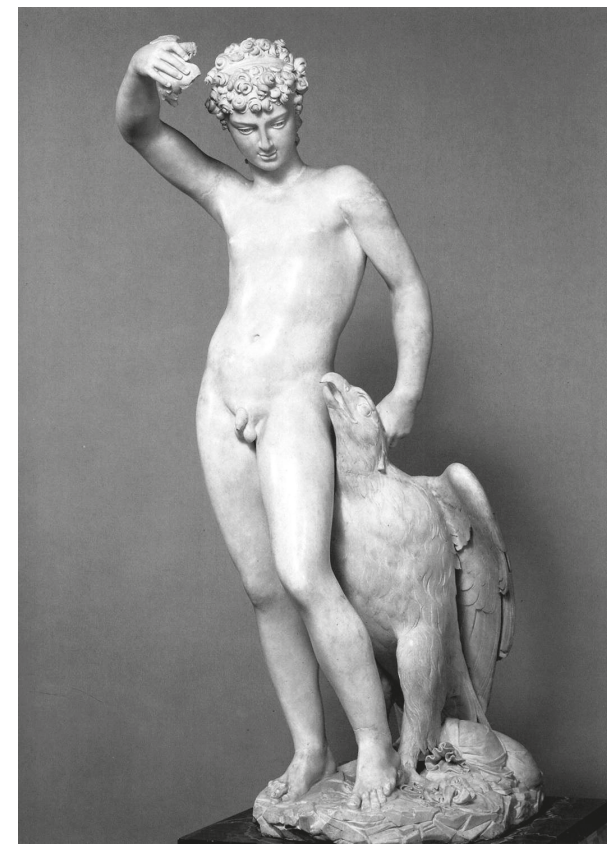

Fig. 2. B. Cellini. Ganymede. Museo Nazionale del Bargello, 1540s. Available at: https://commons.wikimedia.org/wiki/ File:Cellini_-_Ganymede,_05marble.jpg

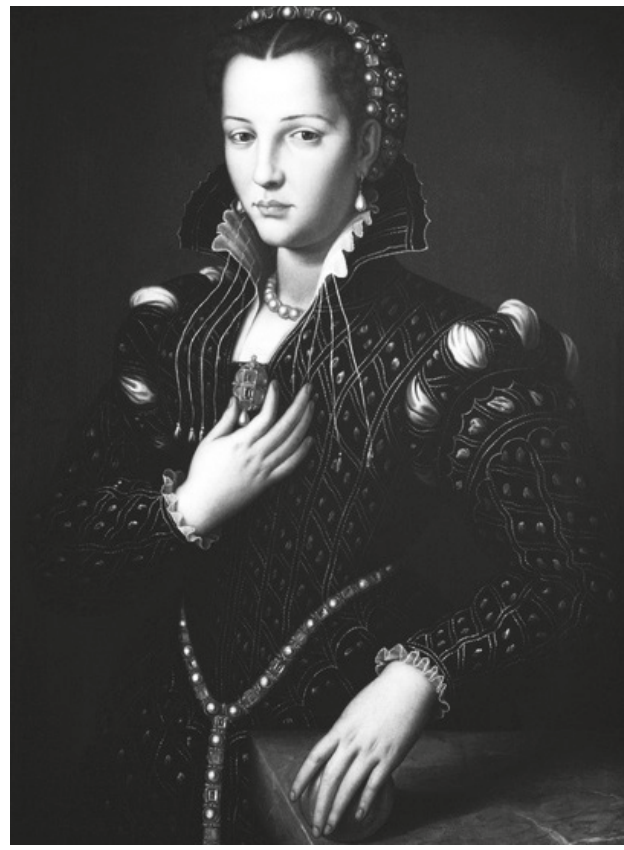

Fig. 3. Bronzino. Portrait of Lucrezia de'Medici. North Carolina Museum of Art, 1560. Available at: https://www. wikidata.org/wiki/Q63803412

ingegnoso Pittore, piuttosto grande, e finissimo oro, che piccol bronzo, ritratta, e scolpita artificiosamente di naturale. Tale, e tanti furono in questo raro, anzi solo altero, e dolce mostro di Natura i beni del corpo. Ma molto più, e molto maggiori, siccome ancora vie migliori, quegli dell'animo, ...4

Varchi's oration followed a well-trodden path: reviewing the virtues of the deceased along the distinction between the fortune, body, and soul.

Though seemingly laudatory for the beautiful sitter and her painter, evoked by Varchi through a flattering pun ${ }^{5}$, the beni del corpo (body goods) were under-rated in comparison to beni dellanima (moral and intellectual virtues) he would review further on. Despite his friendship and admiration for the dotta e maestrevole hand of a saggio ed ingegnoso painter, Varchi couldn't help exploiting pro domo the opposition between extern and intern qualities, the first entrusted to painters, the second to orators; a cleavage he himself had theorized in the Two lessons $(1550)^{6}$. In a mourning situation, the dispute between poësis and pictura could be rephrased as: which of them would better serve the deceased?

4 [18], Varchi's funeral orations would be republished by Francesco Sansovino in a miscellany [15, 2, p. 29]. The translation and underlying is ours.

5 His painting was more akin to gold (oro) than eponymous bronzo.

6 “... pare che sia tanta differenza fra la Poesia \& la pittura, quanta è fra l'anima e 'l corpo. Bene è vero, che come i Poeti discrivono anchora il di fuori, cosi i Pittori mostrano quanto più possono il di dentro, cio è gl' 
Lateral questions may be raised by these two portraits: what effect had the recycling of a portrait made of a living sitter in a funeral setting? What effect an image had on a bereaved viewer $^{7}$ ? To what extent could death be enlisted in the paragonian disputes?

\section{Quæ pingi nequeunt}

It was not the first time Varchi took advantage of a funeral occasion to criticize painting. An epitaph he had written for a young and handsome friend offers a previous meditation on the subject:

sub imagine Iulii Gondii
Talis erat primis, \& pubescentibus annis
IULIUS, Elysias mox subiturus aquas
Cætera, quæ pingi nequeunt, cognoscere si vis,
Tolle necem, æternis par fuit ille deis ([5, p. 165], also [10]).

We don't know who drew the portrait of G. Gondi exhibited at his funeral and under which Varchi wrote his poem, nor when this piece of poetry was written: probably in 1526, as Gondi died before the siege. One must acknowledge Varchi's long-lasting grief. Not only did he write several sonnets in Italian on Gondi's death [20, II, CXXIX, CXXXI, CXXXII, p. 851], but paid him tribute in the Storia fiorentina ${ }^{8}$ and published the Latin tetrastikon in a miscellany of Carmina (1562).

Despite a faithful depiction (talis), the portrait was not satisfactory nor fulfilling. This harsh judgment on painting, only capable of rendering the physical appearance, could be a milestone, as Varchi would later mitigate his first judgment or prejudice. This early critic of pictura might have platonic overtones: it did not seem possible to rise through painting from a beautiful appearance to a beautiful essence. But one may maliciously doubt the image did not do justice to Gondi, as Varchi insisted again and again in his poems on Gondi's outstanding beauty, the kalos kai agatos type.

Through periphrasis and litotes - "Cætera, quæ pingi nequeunt" - Varchi pointed out a pictorial adynaton, going as far as making a bold suggestion: if one wanted to know the things which can't be painted - Gondi's inner self? Gondi's real qualities? -, see over, he would have no alternative than "tolle necem" ? Hence, a cupio dissolvi, not at all exceptional in Varchi's funeral poetry9. Did he not go so far to evoke the philosophical suicide of Cleombrotus in

affetti \& il primo che ciò anticamente facesse questo, secondo che racconta Plinio, fu Aristide Thebano \& modernamente Giotto" [21, pp.412-427].

7 According to a fortunate Plinian anecdote, drawing had an intrinsic relation to absence: the portrait was meant to keep, first, then, conjure the illusion of the absent person, as encapsulated by the Plinian story of the daughter of Butade (NH, XXXV, 151-153) who kept her departing lover by drawing his profile, later carved by his father. If the person was dead (definitely absent), the stakes and pathos were even higher. Only portraits (drawn, painted or sculpted) could, though, deceptively, fill the void.

$8 \quad$ [20, II, p. 104] In spite of his desperate stance: "Dopo te nulla piacque aglocchi miei", (After you nothing ever pleased my eyes) Gondi had many successors: Lorenzo Lenzi, object of an important commission from Varchi to Bronzino, usually considered the starting point of their friendship.

9 See, for instance, about Tribolo’s death: "Ma piango il comun danno, e vorr'anch'io/ Uscire omai di questo carcere fore" [20, II, p. 855]. 
Michelangelo's funeral oration to illustrate the desirability of death from a philosophical point of view $[19$, p. 61]; a rather surprising call in a catholic church?

\title{
Il caso orrendo
}

In 1562 Eleonora, Giovanni, and Garcia died.

This gave Varchi and Bronzino a new but terrible opportunity of working together. To be sure, Varchi was sincere in writing ejusdem ad seipsum (of himself to himself) a poem in which he pledged that he would rather die in the cradle or as an infant than grow old and grey and witness such a caso orrendo:

\author{
Infelix BENEDicte hæc sunt, quæ sera senectus \\ Dona dat; hæc affert munera longa dies. \\ Tristia Medicei vidisti funera sacri \\ Herois nimis heu, heu properata nimis. \\ Quàm melius si canitiem mihi fata negassent ? \\ Quàm mallem in cunis, vel perïysse puer? [14, p. 104]
}

Varchi brought the bad news to Bronzino who, being ill, was indisposed. So, Varchi, via a sonnet informed Bronzino, presuming a desperate reaction from the painter that he would rather die than recover once he learned of the tragedy:

Esser morto più tosto, che guarito

Da si lungo, e si reo languor vorrete

Cortese Bronzin mio ; quando saprete

Che'l gran Giovanni fu da Noi partito.

E che poco di poi l'hebbe seguito

Il bello, e buon Grazia, ma che piangete

Si forte, lasso ! e ancora non sapete

Che'l terzo sole è spento, anzi sparito!

Che la Donna Real pria che segnato

Le fusse il giorno suo, volle partire

Lasciando il Mondo tristo, e sconsolato.

E’l gran consorte suo rotto, e piagato

Da tai tre colpi, senza sdegni et ire

Non ebbe pur, nèll volto ancor cangiato. [4, p. 36]

It might have occurred to Varchi that the two of them would be associated in the funerals of the trio as they had been two years earlier for Lucrezia. But Bronzino's response would not be pictorial but poetic: no less than 12 sonnets, at least those published by D. Moreni in his edition of 1823 [4, pp.36-42]. Varchi's sonnet turned out to be a proposta which Bronzino would answer with 12 sonnets of risposta. As usual, Varchi provided the poetic rails that Bronzino would follow.

The unexpectedness, rapidity, and horror (rumors of fratricide and even infanticide circulated) of the triple death might explain why the trio's funerals were rushed. Thanks to a chroni- 


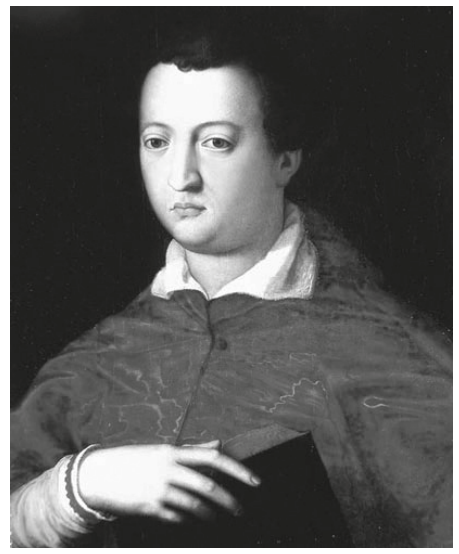

Fig. 4. Baccio Lomi. Portrait of Giovanni de'Medici after Bronzino, 1560. Available at: https://images.app.goo. gl/9nMac99iilztyL559 cler (A. Lapini) and a scholar (P. Moreni), we have a few details of the funerals ${ }^{10}$ : corpses were not showed, as they had been sparati (open) for autopsy; no simulacro (wax model) was made for Eleonora [13, p.52], neither were there any magnificent portraits painted by Bronzino, immortalizing her beauty. Varchi would not be chosen either for the funeral orations. They were entrusted to Pietro Vettori [22] and Giovanni Battista Adriani for Leonora, Lionardo Salviati for Garcia, Giovanni Guadagni for Giovanni.

In addition to these instant books, poetic miscellanies were published.

In one of them, Poesie toscane et latine di diversi eccell. Ingegni, nella morte del S. D. Giovanni cardinale, del Sig. Don Grazia de Medici, \& della S. Donna Leonora di Toledo de Medici Duchessa di Fiorenza, et di Siena (1563) [14], Varchi is ubiquitous as Bronzino hinted in this verse: "il caso orrendo, e mai più non udito,/Che tanto pianto, e celebrato avete".

Varchi seems to have played a pivotal role in this miscellany of poems (in Latin and vulgar), being, by far, the most quoted name, not only as author of "Garsiæ Medices Tumulus", "Elenoræ Toletanæ Tumulus" [14, p. 32] and other pieces, but also as dedicatee of a huge quantity of proposta and risposta compositions, a scheme he had experienced and promoted in his own correspondence poetry.

If Eleonora's portrait seems not to have been exhibited during the funeral, there are contradictory clues regarding Giovanni's portrait (Fig. 4$)^{11}$ : the first is a sonnet of Bronzino to his friend Varchi, in which the painter said he was reluctant to porgere (present ${ }^{12}$ ) the portrait of Giovanni to his father:

O del più bello, e più nobile, e santo

Angel più che mortal, sebben da umile

Dipinta mano, imagine gentile,

Che sì tosto ogni gioia ha volta in pianto,

Come fia mai, chal mio Signor, cui tanto

Caldo sacrai i color, l'arte, e lo stile

10 "There is no visual record of Eleonora's funeral, but the decorations must have been similar to those in San Lorenzo for the funeral of Michelangelo" [16, p. 230]. Garcia went buried "senza pompa alcuna"(with no pomp), on the fourth of December, whereas Giovanni had got a "grand ceremony" on the $25^{\text {th }}$ of November but his body would not be "esposto alla pubblica vista" [13, p.91]. Eleonora would follow on the $28^{\text {th }}$ of December with "no effigy". Cf. [16, pp. 225-266].

11 Giovanni de'Medici was portrayed as a child or teenager many times by Agnolo di Cosimo Tori, alias il Bronzino, and also by Francesco Salviati. As a young cardinal, portraits were made by the same Bronzino (Galleria degli Uffizi). Garzia was portrayed as a child by Bronzino four times and by Lorenzo della Sciorina, with his mother. (Cf. Vasari, G6 ACCAD, p. 237.)

12 Did Bronzino mean presenting a new copy for the funeral of the portrait he had made? Did he consider the portrait though commissioned and delivered, always belonged to a certain extent to his author? 
Ti porga ? or troppo al ver forse simile,

Ch'io tenea poco, e Dio non mè ne vanto;

Nè mi spavente rinnovarli il duolo

Del tuo stinto esemplare, e del buon Frate

Morto, e della sua spenta alma Consorte?

Nol farò, dunque, ancor ch'io sappia solo

Egli aver tanto al Ciel l'ali innalzate,

Che qui nol cangia o buona, o trista sorte. [4, p.39]

The sonnet offers a rare insight into the psychological impact of the portraits of the deceased on the bereaved; a key topic of this paper. Contrary to a commonplace opinion, the image of the deceased didn't necessarily bring solace or comfort, but added to the grief, argued Bronzino, as if the mimetic power of images backfired. In this early stage of grief, images could worsen the situation instead of consoling the mourner. Grief stricken, Cosimo, a husband and a father, would be the main spectator of this exhibition and would find these portraits unbearable.

Notwithstanding the extraordinary resemblance, he did not "or" (presently) praise it that much, nor felt like boasting about it, as he felt nearly appalled by this excessive resemblance "troppo al ver forse simile"(too much similar to the true), which could only "rinnovar"(renew) the grief for the deceased "stinto esemplare" (extinguished model). The sonnet expresses the author's recoiling at this too bold, (troppo ardito) power, to put it in Pontormo's words [21, p. 460], Bronzino's master; a topic that Cellini would on the contrary exploit in his militant poetry to claim the almost demiurgic sculpture at the expense of the only imitative painting.

Sua sponte Bronzino seemed to abdicate his professional pride, this godlike power of creating life or giving the illusion with which he had played in his youth with the Pygmalion and Galatea painting (1529-1530). In this meta-artistic work, Bronzino identified himself to Pygmalion, the artist-creator and proved at the same time the painter's capacity to figure a sculptural myth. An older and ill Bronzino no longer felt like playing with these tricks in too tragic a situation. He preferred to withdraw his portrait, afraid of the extra pain he could inflict on an already devastated father and husband.

Bronzino's verses also drew on the trompe l'ceil topos, a major pride of the champions of painting: the capacity paintings had to fool the viewer (birds, animals, human beings...) In this case, it is as if the illusionistic power of painting backfired, producing not wonder or pleasure, but pain and anguish.

One might doubt Bronzino's sincerity, though. The poem also betrays a high level of self-consciousness, reminding the Duke how he had dedicated "colours, art, and style" to him and contributed to the celebration and idealization of the Medici family. The three deaths could also have been an opportunity for coming back on the front scene for an artist who would be marginalized by Vasari and the upcoming generation. Bronzino's qualms could also be an astute manner reminding the Duke of the high quality of his portraits of the ducal family. No one could compete with Bronzino. The outstanding portraits he had made of the whole family were likely to become the portraits of the deceased, as we have already seen from the portraits of Stefano Colonna and Lucrezia de'Medici. Over time, Bronzino's gallery of medicean portraits became a graveyard. 
The second clue we have in favor of the presence of a portrait of Giovanni during the funeral is a tetrasticon written 'under the image' of the deceased and published by Varchi in the Poesie:

Sub imagine eiusdem

Cernis Ioannem Medicen, non qui fuit olim

Orbis delitiæ, Papa Leo Decimus

Sed qui olim fuerat (servassent fata) futurus

Orbis delitiæ, Papa Leo Undecimus. [14, p. 102]

If the poem is in se no masterpiece or a typical encomiastic work, fantastically fulfilling the family plans in presenting the one who had been elected cardinal in 1560 by his uncle, Pius IV, as the fourth Medici pope ${ }^{13}$, highly interesting is the sub imagine genre Varchi had already used for Gondi.

At the crossroads between pictura and poësis, this sub genre ${ }^{14}$, close to titulus, does not seem to have drawn the attention of the critic, though offering a perfect paragonian format.

\section{Cellini's son}

One year later another father lost another son. The precocious death of Giovanni gives us a different view of Cellini: not the usual braggart but a desperate father, converting his grief in the project of a simple tomb, which would eventually be his ${ }^{15}$.

Minimalist as it was, Giovanni's tomb encapsulates the essence of the collaboration between the artist (Cellini), busy with the conception and ornaments on the deposito (coffin), and the literate (Varchi) in charge of the written part: the epitaph. Cellini asked Varchi to correct, complete, maybe translate the first draft of the epitaph he had himself written:

E perchè egli mi è piaciuto fargli per mio contento un poco di lume, ho avuto grazia da' frati della Nunziata che mi hanno concesso che io facia un deposito di lui insino a tanto chegli piaccia a Dio che io me ne vada a dormire a canto a lui in un poco di sepoltura qual potrà farsi dalla povertà mia a quell tempo. Intanto io voglio fare dipignere questo dipositino con due Angeletti con le faci in mano, ed in mezzo a essi uno epitaffio il quale io mostro con questo mio rozzo modo e in atto quello che io vorrei: che voi con quelle vostre mirabilia virtudi molto meglio direte quello che io vorrei dire; e piacendovi farlo latino o Toscano tutto rimetto a il vostro infallibile iudicio; e se io vi affatico, a questa volta perdonatemi e comandate a me, che sono per servirvi sempre paratissimo. Di Firenze a gli xxij di maggio 1563 [7, II, p. 644].

Il concetto che io desidero che sia espresso da voi si è : giovan Cellini a Benvenuto solo / Figlio qui iace: Morte al mondo il tolse/ Tenero d’anni. Mai le Parche sciolse/Tal speme in fil da l'uno a l'altro polo.

Sempre partissimo alli servizii di V.S. [6, II, p. 638].

\footnotetext{
13 Giovanni was meant to be elected pope, after Leone X, Clemente VII, Pio IV.

14 We found other sub imagine pieces in Varchi's latin production, published or not, mostly in miscellanies. We'll mention "sub imagine Iuliani Medices" (10); "sub effigie Leonorae Florentiae Ducis" (42); "sub imagine Henrici Francorum regis" (104); "sub imagine Benedicti Albitii" (136); "sub effigie Philiberti Aurantii principis" (142); "sub imagine Dominici Venerii" (220); "in aeneam effigiem Philippi Britanniae regis a Leonte Arretino excusam"; a precious anthology of latin poetic reviews of works of art by Varchi. The Latin Carmina of Varchi are available online http://mizar.unive.it/poetiditalia/public/indici/autori/idautori/292. Some of these poems might have been written for Giovio's Elogia but would never be published Cf. [12].

15 In his will of 18.12.1570, Cellini expressed the wish to be buried in the "Nunziata" in a tomb he was always planning to carve himself, one year before his death. If he did not succeed, he wished to be buried in the common tomb set for painters, which happened. Cf. [6, II, p. 706].
} 
Cellini always trusted Varchi's taste and knowledge in their long-lasting friendship: he asked him to write the Latin motto of the Bembo's medal and later the sentences "in base Persæi a Benvenuto Cellini excuse" $[10,134]$ of his Perseus, to read and correct his Vita, a mission Varchi notoriously and fortunately refused. It is likely Varchi reread and supervised everything Cellini wrote, but it would be limitative to think of their relation only in these terms, as Cellini turned out to be one of the major artist-writers Varchi recruited for his anthology. The letter Cellini wrote to Varchi in 1546 became the matrix of all his further literary writings.

\section{Michelangelo's funerals (1564)}

Another well-known funeral would play a major role in Cellini's life, his thoughts, and his writings: Michelangelo's funerals. These coincided with the launch of the Accademia del Disegno. Again, we find Varchi, Cellini, Bronzino, as well as many other artists and litterati associated to this event: Varchi as an orator and iconograph of the funerals held in San Lorenzo, Bronzino and Cellini as "deputies" in charge of the iconography of the event.

It is of no surprise that Cellini was so taken by Michelangelo's tomb; an amazing project which he probably would have dreamt of achieving himself. His catafalque project, highly indebted to Varchi's ideas had been dismissed as his seal project for the Academy. After his humiliation, Cellini had no choice but to leave angrily: self-ejecting from the committee and adding to his dissent by his conspicuous absence on the day of the ceremony.

But from the outside, he persisted skirmishing on the place of the statues of Painting and Sculpture allegories in the catafalque, publishing an essay on the subject, Discorso sopra la differenza nata tra gli Scultori e Pittori circa il luogo destro stato dato alla Pittura nelle Essequie del gran Michelagnolo Bonarroti. Michelangelo's death offered a pretext in resuming the dispute. The point was to challenge the separation between "fare" (Accademia del Disegno) and "ragionare" (Accademia Fiorentina), an institutionalization of the paragone, based on the outdated superiority of liberal arts on mechanical ones. Not only this grid was at odds with the reality of creation and the ideas of the most brilliant artists of the time, especially of those Varchi had involved in his anthology, but it was completely contrary to Michelangelo's exemplum, at least, as Varchi had coined it.

On one hand, we cannot help noticing the apparent downsizing of Cellini's ambitions and critics. On the other hand, we can only but admire the conversion of this denied and impossible action in vis litteraria which would transform the old or banned sculptor into a real writer, leading to a prolific literary season which would entail the redaction of theoretical works and technical treatises fuelling his poetic inspiration with the "Sonetti intorno alla disputa di precedenza fra la scultura e la pittura", a remarkable meta-artistic poetic corpus.

As for the dispute between pictura and poësis, Michelangelo, Bronzino, Vasari, and Cellini's writings proved Varchi's point in that there are various ways of expressing one's talent.

In the meantime, the iconography of the Apparatus of San Lorenzo in which we believe Varchi played a major role would celebrate the dépassement of the paragone approach mirrored in its written manifesto: Varchi's funeral oration.

Varchi, in 1547, addressed the pictura poësis topic on the basis of the separation and hierarchy between extern and intern qualities and mechanical and liberal virtues. In 1564, he would qualify them "blood sisters" in the name of their common essence: Aristotelian mimesis, which 
was nothing other than the extension of the brilliant gimmick ${ }^{16}$ which had ended the dispute between painting and sculpture in 1547 to poetry and painting:

la pittura, e la poesia sono sorelle carnali, non essendo altra amendue, che imitazione; $[19, \mathrm{p} .40]$

It is as if Varchi had realized at the end of his life, that the differences between painting, sculpture, and poetry were definitely all accidental: unessential.

In 1547, it was too early to abolish the gap between mechanical and liberal arts, though Da Vinci had already done it, but very few knew to what extent.

In 1564, nearly twenty years after, Varchi got access to Leonardo's texts and library. Michelangelo would embody the overcoming or the end of paragone and paragonian frame of mind. Painting, sculpture, architecture, poetry, and rhetorics would be enlisted to celebrate a "monster": triplex artist but also poet, philosopher and theologian, according to Varchi : "un solo, che valse per piu di cento mila" $[19$, p. 15].

In Michelangelo's funerals, pictura, poësis, and mors showed up again and confirmed how well they worked together. Words, mottoes, tituli, poems, and orations were ubiquitous and intertwined with images.

Hence, death offered a new occasion to think about pictura and poësis and to bury the outdated ${ }^{17}$ paragonian approach as Michelangelo's funerals illustrated the converging and complementarity of all arts, writings, and languages. The varchian Michelangelo, the 'monster', as he labeled him in a pre-baroque way, embodied this dépassement.

\section{Final chassé-croisé}

While Bronzino opted for writing rather than painting to address the caso orrendo, and Cellini engaged in his literary career, following the tracks of the michelangelesque model set by Varchi in the Funeral oration: an artist-writer/thinker, Varchi seemed to acknowledge in extremis the power of image. A sonnet he wrote to Bronzino bears testimony of his satisfaction with his portrait painted by Alessandro Allori. Allori, Bronzino's pupil and adoptive son, made his portrait in a fresco figuring Christ in the middle of the doctors.

E se' vostro Alessandro al primo fiore

La bell'opera ha fatto, ove ancor io

Sempre vivrò fuor del comune oblio,

Solo è stata di Dio grazia e favore. [4, p. 47]

\footnotetext{
16 "Dico dunque, procedendo filosoficamente, che io stimo, anzi tengo per certo, che sostanzialmente la Scultura e la Pittura siano un'arte sola, e conseguentemente tanto nobile l'una quanto l'altra, ed a questo mi muove la ragione allegata da noi di sopra, cio è che l'arti si conoscono dai fini, e che tutte quelle arti, che hanno il medesimo fine, sono una sola e la medesima essenzialmente, se bene negli accidenti possono essere differenti" [21, p. 384].

17 It would be misleading to think that Bronzino and Varchi kept entrenched positions, not only because Bronzino as a painter and poet was also capable to render physical and moral qualities, according to such a distribution, but because this comparative and competitive discussion had helped forging a new ideal of a painting capable, precisely, of addressing outside and inside qualities, as would exemplify Bronzino's portraits - from Lorenzo Lenzi (1529) to Ugolino Martelli (1537), from Luca Martini to Laura Battiferri (1555-1560), all of them Varchi's lovers, pupils or protégés - whose intellectual and cultural qualities were conveyed through pictorial devices. Cf. [9].
} 


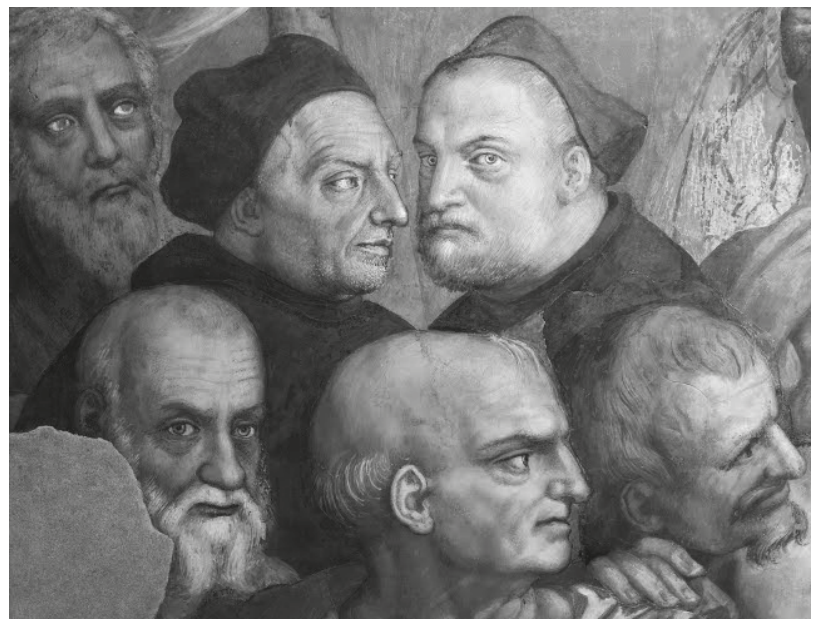

Fig. 5. A. Allori. "Portrait of B. Varchi" in Christ disputing with the Doctors. Cappella Montauto, Santissima Annunziata. 1560-1564

This sonnet gives important evidence of the certainty that this portrait was made during Varchi's life, of his satisfaction for la bell'opera (Fig. 5), but also as a projection in a posthumous reception (two years before his death). It is as if Varchi seemed to realize for his own sake how powerful an image could be and also being able to save him from commune oblio (common oblivion).

It seems another portrait, carved in the marble, was planned for Varchi's tomb, according to In effigiem Benedicti Varchii written by one of his late protégés, Piero Angeli da Barga.

Hic ipsum Varchii posuit de marmore vultum

Atque uno in vultu tres tibi nosse dedit

Historicum, qualem quisquam vix legit : et ulli

Qualem Oratorem nec meminisse queant :

Vatem autem, cui pauci audent contendere vates ;

Sive illos Latium, Tuscia sive tulit. [1]

Vincenzo Danti ${ }^{18}$, a sculptor belonging to the second generation of Varchi's clan who would follow Michelangelo's footsteps in writing Delle perfette proportioni (1567), is likely to be the author.

After having written so many funeral orations, sonnets in death, tumuli, epitaphs for others, Varchi would eventually focus on his own death ${ }^{19}$.

As he had unwillingly anticipated Cellini's death, object of a famous sonnet "In la creduta e non vera morte di Benvenuto Cellini" $[2,1,84]$, written in 1535 on a false rumour, Varchi

18 The sculptor Vincenzo Danti with whom he exchanged poems, later published in Varchi's Sonetti spirituali (1573) succeeded in Varchi's stanze (appartments), al monasterio degl'Angeli. Vasari testified of a "ritratto di basso rilievo, che sarà bellissimo" (G6 ACCAD. p. 249) for the funeral monument planned for Varchi cf. [8; 11]. 19 Interestingly enough whereas Vasari had distanced himself from the epitaphs in the Giuntina edition, contrary to the humanistic Torrentiniana, Varchi seemed to be more and more interested by it. Cf. [23]. 
would deliberately anticipate and plan his own death, writing a series of 40 epitaphs for his own tomb and inventing an autobiography sui generis. Epitaphs were not supposed to be written by the defunct. In writing his own epitaphs, Varchi managed to express his political views, confirming his republican convictions:

Varchius exigua hac contentus villula, et ipsos Reges, et regum despiciebat opes. [10, 129]

Some of these epitaphs were sent or dictated to his future biographer and executer of his will, Silvano Razzi, an abbot, who wrote Varchi's biography and was also an amateur artist ${ }^{20}$.

E'l mio buon RAZZI in qualche marmo, o legno

Segnerà : Forestier, quei che qui giace

Tutte hebbe al fin l'humane cose a sdegno [20, p. 987].

Writing his own epitaphs ante mortem allowed Varchi to gain control of his own image and posterity, which had previously been tarnished by envy and calumny during his lifetime.

The epitaphs were also supposed to be carved in stone. Even if it seldom happened, for technical and financial reasons, this virtual support determined the length, content, and language of these short pieces. One cannot help noticing that Varchis last poetic infatuation was a homage or a clin d'eil to sculpture and remember Michelangelo had written fifty epitaphs for Cecchino Bracci. One cannot help noticing that Varchi's last poetic infatuation was a a clin d'oeil to sculpture.

We might also remember Michelangelo's attraction to epitaphs: a perfect meeting point between poetry and sculpture? Didn't he write fifty of them for Cecchino Bracci? ${ }^{21}$

\section{Литература}

1. Bargeo. Carmina, 2. 20. URL: http://www.poetiditalia.it/texts/BARGAEUS|carm|002 (дата обращения: 01.02.2021)

2. Benvenuto Cellini. Vita / Ed. E. Camesasca. - Milano: Rizzoli, 2007. - 691 p.

3. Bonciani F. Sulla maniera di fare le Orazioni funerali. Ragionamento didascalico. - Firenze: per il Magheri, 1824. $-105 \mathrm{p}$.

4. Bronzino. Sonetti di Angiolo Allori detto il Bronzino ed altre rime inedite di più insigni poeti. - Firenze: nella stamperia Magheri, 1823. - $247 \mathrm{p}$.

5. Carmina quinque Hetruscorum poetarum, nunc primum in lucem edita. [Francisci Vinthae, Carminum libri II, Ecloga I. Fabii Segnii, Carmina. Francisci Bernii, Carmina. Benedicti Accolti,... Epigrammata. Benedicti Varchii, Epigrammata. Insuper, Pompeiani et Eusthenii,... duo addita epigrammata]. — Florentiae, apud Juntas, $1562 .-184 \mathrm{p}$.

6. Cellini B. Vita di Benvenuto Cellini: scritta da lui medesimo tratta dallautografo per cura di Giuseppe Molini. - Firenze, Tipografia all'insegna di Dante, 1832. - 373 p.

7. Cox-Rearick J. The Posthumous Eleonora. The Cultural World of Eleonora di Toledo: Duchess of Florence and Siena. - Routledge, 2004. - P. 225-266.

8. Davis C. La 'Madonna del Monasterio degl'Angeli': Danti e l'ambiente intorno a Benedetto Varchi, tra la quiete fraterna e la stanza dei 'Sonetti Spirituali // I grandi bronzi del Battister / Ed. B. Paolozzi Strozzi. Florence: Giunti, 2008. - P. 164-203.

20 He collaborated to Vasari's Giuntina and favoured the stay of artists in his monastery-studio. Cf. [8].

21 I'd like to thank my friend, Gilian Andrew, who discussed and reread this paper. 
9. Geremicca A. Agnolo Bronzino. "La dotta penna al pennel dotto pari". - Roma, Universitalia, 2013. $351 \mathrm{p}$.

10. Liber Carminum Benedicti Varchii / Ed. A. Greco. - Roma, Abete, 1969. -168 p.

11. Lo Re S. Il volto nel marmo: caccia al Varchi perduto // Varchi e altro Rinascimento: Studi offerti a Vanni Bramanti / Eds. S. Lo Re, F. Tomasi. — Manziana, Vecchiarelli, 2013. - P.61-80.

12. Minonzio F. Con l'appendice di molti eccellenti poeti. Gli epitaffi degli Elogia degli uomini d'arme di Paolo Giovio. - Lampi di Stampa, 2012. - 232 p.

13. Moreni D. Pompe funebri celebrate nell'imp. e real basilica di San Lorenzo dal secolo XIII. a tutto il regno mediceo. - Florence, Magheri Publ., 1827. -374 p.

14. Poesie toscane et latine di diversi eccell. Ingegni, nella morte del S. D. Giovanni cardinale, del Sig. Don Grazia de Medici, \& della S. Donna Leonora di Toledo de Medici Duchessa di Fiorenza, et di Siena. - Fiorenza, L. Torrentino, 1563.

15. Sansovino F. Delle orazioni volgarmente scritte, vol. 2. - Lione: G. e Vincenzo Lanais, 1741. - 850 p.

16. Schraven M. Festive Funerals in Early Modern Italy: The Art and Culture of Conspicuous Commemoration. - Farnham and Burlington, VT: Ashgate, 2014. - 338 p.

17. Varchi B. Orazione funerale, sopra la morte del signore Stefano Colonna da Palestrina, fatta et recitata da $\mathrm{m}$. Benedetto Varchi. - In Firenze, Lorenzo Torrentino Publ., 1547.

18. Varchi B. Orazione funerale fatta, et recitata da m. Benedetto Varchi nellessequie dell'illustrissima, \& eccellentissima signora donna Lucrezia de' Medici, duchessa di Ferrara, nella chiesa di S. Lorenzo, agli xvi maggio. Lanno 1561. - In Fiorenza, appresso i Giunti Publ., 1561.

19. Varchi B. Orazione funerale di $\mathrm{m}$. Benedetto Varchi fatta, e recitata da lui pubblicamente nellessequie di Michelagnolo Buonarroti in Firenze, nella chiesa di San Lorenzo ... - In Firenze, appresso i Giunti Publ., 1564.

20. Varchi B. Opere di Benedetto Varchi ora per la prima volta raccolte, 2 vols / Ed. A. Racheli. - Trieste: Lloyd austriaco, 1859. - XX, 626, $1029 \mathrm{p}$.

21. Varchi B. Deux leçons sur l’art (Travaux du Centre d'études supérieures de la Renaissance) / Ed. F. Dubard De Gaillarbois. - Paris, 2020. - 551 p.

22. Vettori P. Laudatio Eleonoræ Cosmi Medices Flor. Et Ser. Ducis Uxoris, quæ habita est IV. Kal. Ian. Florentiæ in Aede D. Laurentii. - Florentiæ, apud Laurentium Torrentinum Publ., 1562.

23. Waldman L.A. A Rediscovered Portrait of Benvenuto Cellini Attributed to Francesco Ferrucci del Tadda and Cellini // The Burlington Magazine. -2007. - Vol. 149. - No. 1257. Sculpture. - P. 820-830.

Title. Varchi, Bronzo, Benvenuto... Ut pictura poësis sub specie mortis

Author. Dubard de Gaillarbois, Frédérique - full professor. Sorbonne Université, 47, rue des Écoles, 75230 Paris Cedex 05, France. frederique.dubard_de_gaillarbois@sorbonne-universite.fr ORCID: 0000-00030006-1375

Abstract. In this paper, we will show how death provided plenty of personal, collective, spontaneous, professional occasions for humanists and artists to work together and to compare their skills. If funeral occasions were initially used by Varchi to prove poësia superiority to pictura according to a predictable and convenient pattern as demonstrated at the funerals of Stefano Colonna, Lucrezia dei Medici, which involved collaborative efforts by Benedetto Varchi and Agnolo Bronzino, he then moved forward. His growing and late predilection for two genres - the "sub imagine" poem and the epitaph, shown at the funerals of Eleonora, Giovanni, and Garcia dei Medici, and through that of Giovanni Cellini, - offered a fortunate, though neglected, synthesis between figurative arts and poetry, allowing him to elaborate a pictorial and sculptural poetry. Michelangelo's funerals, in which Varchi played a major role as an orator and iconographist, enacted the dépassement of the paragonian approach in a baroque funerals, that demonstrate the converging and complementarity of all arts, writings, and languages.

Keywords: death, funerals, paragone, Benedetto Varchi, Bronzino, Benvenuto Cellini, epitaph, de imagine

Название статьи. Варки, Бронзино, Бенвенуто... Ut pictura poësis sub specie mortis

Сведения об авторе. Дубард Де Гайарбуа Фредерик - профессор. Парижский университет Сорбонна, 47, rue des Écoles, 75230, Париж, Франция. frederique.dubard_de_gaillarbois@sorbonne-universite. fr ORCID: 0000-0003-0006-1375

Аннотация. В статье исследуется, как смерть и похороны становились поводом для совместной художественной работы и творческого соревнования среди флорентийских художников и литераторов 
эпохи Чинквеченто. Гуманист Бенедетто Варки первоначально использовал похоронные церемонии, в рамках которых его произведения соседствовали с живописными портретами Аньоло Бронзино, для демонстрации превосходства поэзии над живописью, как видно на примерах процессий, посвящённых Стефано Колонны и Лукреции Медичи. Однако впоследствии его представления, вписывавшиеся в традиционную и предсказуемую схему, претерпевают существенные изменения. Растущее пристрастие Варки к двум жанрам поэзии: "sub imagine" и эпитафии, проявившееся на похоронах Элеоноры, Джованни и Гарсия Медичи, а также Джованни Челлини, - открыло ему путь к синтезу изобразительных искусств и поэзии и позволило разработать «живописную» и «скульптурную» поэзию. На похоронах Микеланджело, где Варки играл главную роль оратора и иконографа, состоялся переход от ренессансного paragone (соревнования искусств) к характерным для стиля барокко сближению и взаимодополняемости словесных и визуальных искусств. На основании новых принципов Варки проектировал собственные похороны, в которых ведущая роль отводилась такому синтезу искусств.

Ключевые слова: смерть, похороны, парагон, Бенедетто Варки, Бронзино, Бенвенуто Челлини, эпитафия

\section{References}

Bargeo. Carmina, 2. 20. Available at: http://www.poetiditalia.it/texts/BARGAEUS|carm|002 (accessed 01 February 2021).

Bonciani F. Sulla maniera di fare le Orazioni funerali. Ragionamento didascalico. Firenze, per il Magheri Publ., 1824. 105 p.(in Italian).

Bronzino. Sonetti di Angiolo Allori detto il Bronzino ed altre rime inedite di più insigni poeti. Firenze, nella stamperia Magheri Publ., 1823. 247 p. (in Italian).

Camesasca E. (ed.). Benvenuto Cellini. Vita. Milano, Rizzoli Publ., 2007. 691 p. (in Italian).

Carmina quinque Hetruscorum poetarum, nunc primum in lucem edita. (Francisci Vinthae, Carminum libri II, Ecloga I. Fabii Segnii, Carmina. Francisci Bernii, Carmina. Benedicti Accolti,... Epigrammata. Benedicti Varchii, Epigrammata. Insuper, Pompeiani et Eusthenii,... duo addita epigrammata). Florentiae, apud Juntas Publ., 1562. 184 p. (in Latin).

Cellini B. Discorso sopra la differenza nata tra gli Scultori e Pittori circa il luogo destro stato dato alla Pittura nelle Essequie del gran Michelagnolo Bonarroti. Scarpellini P. (intr.). Cellini B. La Vita i trattati i discorsi. Casini Publ., 1967, pp. 229-233 (in Italian).

Cellini B. Vita di Benvenuto Cellini: scritta da lui medesimo tratta dallautografo per cura di Giuseppe Molini. Firenze, Tipografia all'insegna di Dante Publ., 1832. 373 p. (in Italian).

Cox-Rearick J. The Posthumous Eleonora. The Cultural World of Eleonora di Toledo: Duchess of Florence and Siena. Routledge Publ., 2004, pp. 225-266.

Davis C. La 'Madonna del Monasterio degl'Angeli': Danti e l'ambiente intorno a Benedetto Varchi, tra la quiete fraterna e la stanza dei 'Sonetti Spirituali. Paolozzi Strozzi B. (ed.). I grandi bronzi del Battistero. Florence, Giunti Publ., 2008, pp. 164-203 (in Italian).

Dubard De Gaillarbois F. Cellini poète et philosophe ou les rêveries d'un sculpteur solitaire. Revue des Études italiennes, vol.55: Poésie et philosophie dans la littérature italienne, no. 4-12, 2009, pp.239-274 (in French).

Dubard de Gaillarbois F. Le portrait du "père de famille" ou le nœud de la filiation dans l'œuvre écrite et figurée de Léonard. Dubard de Gaillarbois F.; Chiquet O. (eds.). Nodi, vincoli e groppi leonardeschi. Etudes sur Léonard de Vinci, Actes Journée détudes. Editions Spartacus Publ., 2019, pp. 137-174 (in French).

Dubard de Gaillarbois F. Proposte per un Varchi iconografo? Kriticè, 2020, no. 1, pp. 115-137 (in French).

Dubard De Gaillarbois F. (ed.). Varchi B. Deux leçons sur l'art (Travaux du Centre détudes supérieures de la Renaissance). Paris, 2020. 551 p. (in French).

Esequie del Divino Michelangelo Celebrate in Firenze dall'Accademia de Pittori, Scultori, et Architettori. Nella Chiesa di San Lorenzo il dì 28. Giugno MDLXIIII. In Firenze, appresso i Giunti Publ., 1564, carta C 2 v. (in Italian).

Ferrone S. (ed.). Varchi B. Epigrammi a Silvano Razzi. Fiesole, 2003 (in Italian).

Gamberini D. (ed.). Cellini B. Rime. Firenze, SED Publ., 2014. 582 p. (in Italian).

Gamberini D. I colloqui poetici degli artisti della corte fiorentina con Benedetto Varchi. La Rivista, 2017, pp. 61-69 (in Italian). 
Geremicca A. Agnolo Bronzino. "La dotta penna al pennel dotto pari”. Roma, Universitalia Publ., 2013. 351 p. (in Italian).

Geremicca A. Sulla scia di Agnolo Bronzino, Alessandro Allori sodale di Benedetto Varchi. Un ritratto 'misconosciuto' del letterato e un suo sonetto inedito. Dubard de Gaillarbois F., Chiquet O. (eds.). Varchi e dintorni. La Rivista, no. 5, 2017, pp. 85-112 (in Italian).

Giovio P. Le Iscrizioni poste sotto le vere imagini de gli huomini famosi, le quali a Como nel museo del Giovio si veggono, tradotte di latino da Hippolito Orio. Firenze, Torrentino Publ., 1552. 258 p. (in Italian).

Greco A. (ed.). Liber Carminum Benedicti Varchii. Roma, Abete Publ., 1969. 168 p. (in Italian and in Latin).

Guadagni G. In Obitu Joannis Med. S. R.E.Card., Gartìe fratris, Eleonore Toletano... Florentiæ, apud B. Sermatellium Publ., 1563. (in Latin).

Lapini A. Diario fiorentino di Agostino Lapini dal 252 al 1596 ora per la prima volta pubblicato da Gius. Odoardo Corazzini, Firenze, Sansoni Publ., 1900. 411 p. (in Italian).

Lo Re S. Il volto nel marmo: caccia al Varchi perduto. Lo Re S.; Tomasi F. (eds.). Varchi e altro Rinascimento: Studi offerti a Vanni Bramanti. Manziana, Vecchiarelli Publ., 2013, pp. 61-80 (in Italian).

Minonzio F. Con lappendice di molti eccellenti poeti. Gli epitaffi degli Elogia degli uomini darme di Paolo Giovio. Lampi di Stampa Publ., 2012. 232 p. (in Italian).

Moreni D. Pompe funebri celebrate nellimp. e real basilica di San Lorenzo dal secolo XIII. a tutto il regno mediceo. Florence, Magheri Publ., 1827. 374 p. (in Italian).

Poesie toscane et latine di diversi eccell. Ingegni, nella morte del S. D. Giovanni cardinale, del Sig. Don Grazia de Medici, \& della S. Donna Leonora di Toledo de Medici Duchessa di Fiorenza, et di Siena. Fiorenza, L. Torrentino Publ., 1563. (in Italian).

Racheli A. (ed.). Varchi B. Opere di Benedetto Varchi ora per la prima volta raccolte, 2 vols. Trieste, Lloyd austriaco Publ., 1859. XX, 626, 1029 p. (in Italian).

Sansovino F. Delle orazioni volgarmente scritte, vol.2. Lione, G.e Vincenzo Lanais Publ., 1741. 850 p. (in Italian).

Schraven M. Festive Funerals in Early Modern Italy: The Art and Culture of Conspicuous Commemoration. Farnham and Burlington, VT, Ashgate Publ., 2014. 338 p.

Varchi B. Orazione funerale, sopra la morte del signore Stefano Colonna da Palestrina, fatta et recitata da $\mathrm{m}$. Benedetto Varchi. In Firenze, Lorenzo Torrentino Publ., 1547. (in Italian).

Varchi B. Orazione funerale fatta, et recitata da m. Benedetto Varchi nell'essequie dell'illustrissima, \& eccellentissima signora donna Lucrezia de’ Medici, duchessa di Ferrara, nella chiesa di S. Lorenzo, agli xvi maggio. Lanno 1561. In Fiorenza, appresso i Giunti Publ., 1561. (in Italian).

Varchi B. Orazione funerale di m. Benedetto Varchi fatta, e recitata da lui pubblicamente nellessequie di Michelagnolo Buonarroti in Firenze, nella chiesa di San Lorenzo ... In Firenze, appresso i Giunti Publ., 1564. (in Italian).

Vettori P. Laudatio Eleonore Cosmi Medices Flor. Et Ser. Ducis Uxoris, qua habita est IV. Kal. Ian. Florentice in Aede D. Laurentii. Florentiæ, apud Laurentium Torrentinum Publ., 1562. (in Latin).

Waldman L. A. A Rediscovered Portrait of Benvenuto Cellini Attributed to Francesco Ferrucci del Tadda and Cellini. The Burlington Magazine, 2007, vol. 149, no. 1257, Sculpture, pp. 820-830.

Wellington Gahtan M. Giorgio Vasari. Collector of Epitaphs. Wellington Gahtan M.(ed.). Giorgio Vasari and the Birth of the Museum. Ashgate Publ., 2014, pp. 1-24. 